\title{
Contribution of fishery and aquaculture products to Turkish foreign trade: An evaluation by a hybrid multi-criteria decision-making method
}

\section{Balıkçılık ve su ürünlerinin Türk dış ticaretine katkısı: Hibrit çok kriterli karar verme yöntemi ile bir değerlendirme}

\author{
Bilgen Akmermer ${ }^{1}$ • Pelin Çelik ${ }^{2}$ \\ 1 Karadeniz Technical University, Faculty of Economics and Administrative Sciences, \\ Department of Business Administration, 61040, Trabzon, Turkey \\ ${ }^{2}$ Karadeniz Technical University, Faculty of Economics and Administrative Sciences, \\ Department of Business Administration, 61040, Trabzon, Turkey \\ https://orcid.org/0000-0003-4201-5254 \\ https://orcid.org/0000-0002-2234-2656
}

*Corresponding author: pcelik@ktu.edu.tr

Received date: 26.12 .2020

Accepted date: 12.04 .2021

\section{How to cite this paper:}

Akmermer, B. \& Çelik, P. (2021). Contribution of fishery and aquaculture products to Turkish foreign trade: An evaluation by a hybrid multi-criteria decision making method. Ege Journal of Fisheries and Aquatic Sciences, 38(3), 275-282. DOI: 10.12714/egejfas.38.3.03

Abstract: Fisheries and aquaculture industry, which provides a continuous and high-return market advantage to potential countries, is also one of the priority industries for Turkey. Although Turkey has important advantages with its geographic position and bio-diversity, the industry's contribution to foreign trade is not at an acceptable level. Accordingly, it is important to evaluate the capture fishery and aquaculture products, which provide the best contribution to the foreign trade of Turkey. Thus, the present paper aims to provide foreign trade executives with an intuition about the most appropriate products to invest in and contributing products to Turkish foreign trade within the scope of market strategies. Entropy-WASPAS, which is a hybrid multi-criteria decisionmaking method, is used for evaluating the contribution of fishery and aquaculture products to Turkish foreign trade. This model includes both criteria (production, import quantity, import value, export quantity, export value) and alternatives (trout, sea bream, sea bass, sprat, atlantic bonito, anchovy, horse mackerel, pilchard, sea snail, prawn, cuttle fish, mussel). Entropy is used to determine the criteria weights, and WASPAS is applied for ranking the fishery and aquaculture products. According to the results, export value is the most important criteria while Sea Bream is found as the most significant product for Turkey's foreign trade.

Keywords: Fishery products, Turkey, decision making, Entropy, WASPAS

Öz: Ülkelere sürekli ve yüksek getiri sağlayarak pazar avantajı sağlayan balıkçlık sektörü, Türkiye için de öncelikli sektörlerden biridir. Türkiye coğrafi konumu ve biyolojik çeşitliliğ ile önemli avantajlara sahip olmakla birlikte, sektörün dış ticarete katkısı olması gereken düzeyde değildir. Buna göre, Türkiye'nin dış ticaretine en çok katkıyı sağlayan balıkçılık ve su ürünlerinin değerlendirilmesi önemlidir. Bu nedenle, bu makale dış ticaret yöneticilerine, Türk dış ticaretine katkı sağlayan ve yatııım yapılabilecek en uygun ürünlerin neler olduğuna dair bir öngörü sağlamayı amaçlamaktadır. Balıkçılık ve su ürünlerinin Türk dış ticaretine katkısının değerlendirilmesinde hibrit bir Çok Kriterli Karar Verme yöntemi olan Entropi-WASPAS yöntemi kullanıııışıı. Bu model kriterleri (üretim, ithalat miktarı, ithalat değeri, ihracat miktarı, ihracat değeri) ve alternatifleri (alabalık, çipura, levrek, çaça, palamut, hamsi, uskumru, sardalya, deniz salyangozu, karides, mürekkep balığı, midye) içermektedir. Kriter ağırlıklarını belirlemek için Entropi kullanıımış olup, balıķılık ve su ürünleri yetiştiriciliği ürünlerinin sıralanması için WASPAS yöntemi uygulanmıştı. Sonuçlara göre, en önemli kriter olarak ihracat değeri, Türkiye'nin dış ticaretine katkı sağlayan en önemli ürün ise çipura olarak bulunmuştur.

Anahtar kelimeler: Balıkçılık ürünleri, Türkiye, karar verme, Entropi, WASPAS

\section{INTRODUCTION}

In the last 50 years, global changes and threats have led to a high global awareness of aquatic ecosystems and the need of managing the ecosystems in a sustainable manner, thus the importance of responsible consumption for fisheries and aquaculture resources has been realized and prioritized globally. The fisheries and aquaculture industry is one of the four sub-industries of agriculture. It has a significant importance in contributing to animal/human nutrition and providing raw materials to important industries. Due to the lack of any other nutritional equivalent, the awareness and demand for seafood consumption are increasing in order to ensure adequate and balanced nutrition of societies (Hixson, 2014).
In the period of 1961-2017, the average annual growth rate of total food fish consumption increased by $3.1 \%$, outpacing annual population growth rate (1.6\%). Also, in per capita terms, food fish consumption rose from $9.0 \mathrm{~kg}$ (live weight equivalent) in 1961 to $20.3 \mathrm{~kg}$ in 2017, at an average rate of about $1.5 \%$ per year (FAO, 2020). According to the expectations of being 9.6 billion in 2050 , the researchers estimate that future generations will experience a significant nutritional problem. Therefore, it is expected that the industry's foreign trade value will increase and the countries, which are successful in trade politics and marketing strategies, will have great opportunities for gaining a high market share. 
The consumption of seafood has also led to a rapid increase in fishery and aquaculture production. According to STATISTA (2020) statistics, global fish production amounted to 177.8 million metric tons in 2019 , of which 86.5 million metric tons came from aquaculture production, while 91.3 million metric tons of fish were captured. It is expected that the contribution of aquaculture to global fish production will continue to grow and surpass total capture fisheries by 2024 . As seen in Figure 1, by 2029 , aquaculture production is projected to reach 105 million tonnes.

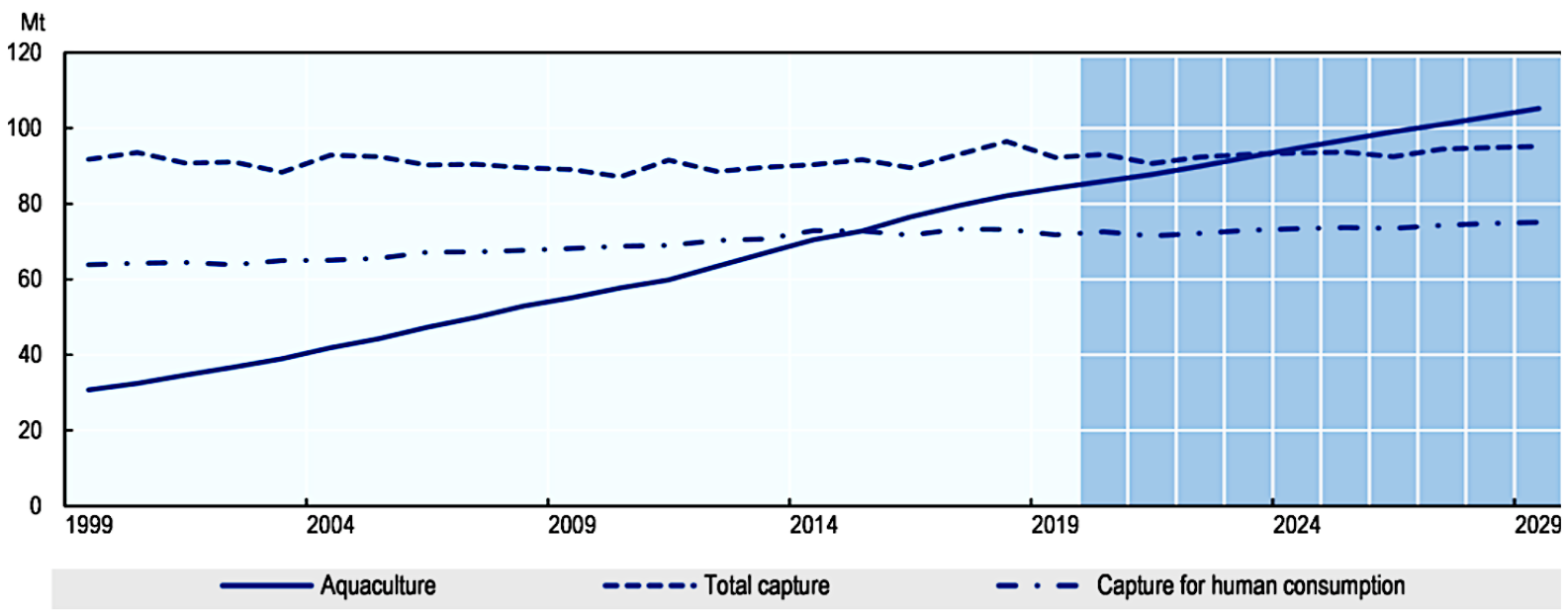

Figure 1. World aquaculture and capture fisheries (OECD library, 2020)

Increases in consumption and growth of aquaculture production have led seafood to be one of the most traded food categories in the world today. From 1976 to 2018, the value of global exports of fish products increased at an annual rate of $8 \%$ in nominal and $4 \%$ in real terms. In 2018, 67 million tonnes of fish (live weight equivalent) were traded



Figure 2. Leading exporting-importing countries in 2018 (FAO, 2020)

Turkey is an emerging country in the industry with its geographic features, biodiversity, and capturing and aquaculture production facilities. There are approximately 500 species in the seas and 370 species in the inland waters, of internationally (FAO, 2020). The global seafood market was valued at 130 billion U.S. dollars in 2018 and it is expected to reach approximately 155.32 billion U.S. dollars by the year 2023 (STATISTA, 2020). The top exporters and the importers of fishery and aquaculture products in 2018 worldwide is given in Figure 2.

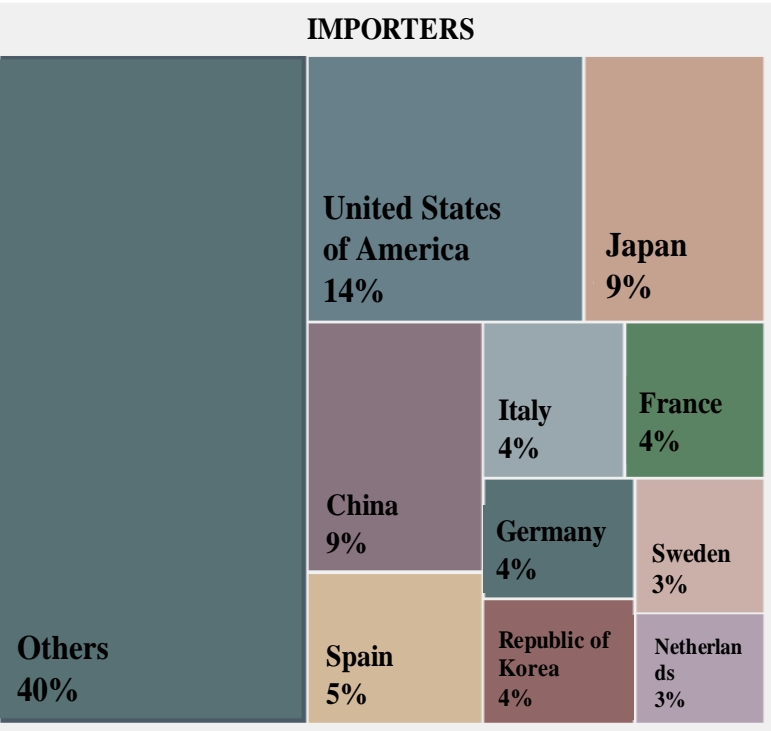

which about 100 are hunted commercially. The production in Turkey is carried by sea and inland capturing and aquaculture production. However, similar to the world, considering the limitation of capturing resources, aquaculture production has 
showed significant improvements in the last thirty years. Especially in recent years, aquaculture production has gained its place among the fastest growing industry. In 2019, the aquaculture production reached 373.356 tonnes, while the capturing production amounted to 463.168 tonnes (Turkish Statistical Institute - TUIK, 2020). Aquaculture production of Turkey is expected to surpass the capturing in the forthcoming years (General Directorate of Agricultural Research and Policy - TAGEM, 2019). The industry also became one of the leading industries for Turkey's foreign trade thanks to increasing numbers in production. Turkey has an increasing export capacity and enlarging its target markets.

In 2019, Turkey exported to 81 countries with a quantity of about 200.226 tonnes with a total sale value estimated at 1.025 billion U.S. dollars. $62 \%$ of the exports were made to the EU countries, and the Netherlands, Italy, and Russia were the most exported countries (TUIK, 2020). However, in the current situation, Turkey has not yet shown its real potential for foreign trade sufficiently. In order to manage effective foreign trade policy, it is crucial to focus on product selection and evaluate which of them contribute to foreign trade effectively. Therefore, this research aims to evaluate the current contribution of leading fishery and aquaculture products (given in Table 1) to the foreign trade of Turkey and also specify the products which are more valuable and able to create currency inflow. The results provide intuition to the foreign trade executives about the most contributing fishery products to Turkish foreign trade. Also, it offers the occasion of showing the most appropriate products to invest in within the scope of a market development strategy. Hence, this is a multi-criteria decision problem, so Entropy and WASPAS methods, which are among the MCDM methods, were used for the efficiency analysis of the determined products.

In this study, Entropy and WASPAS methods were used in an integrated way. When the literature is examined separately for Entropy and WASPAS methods, many studies stand out. However, only five studies in which two methods were used together were found.

Ali et al. (2021) focused on developing an effective way to cope with multi-criteria group decision making problems and they evaluated a supplier selection problem with EntropyWASPAS method. Akçakanat et al. (2017), evaluated the performance of small, medium and large-scale banks using Entropy, and WASPAS methods. Criterion weights were determined by the Entropy method and the WASPAS method was used to rank the banks. Ural et al. (2018), evaluated the performance of three state-owned banks in an integrated manner with the data obtained from the financial statements for the period of 2012-2016 and applied the Entropy and WASPAS methods. Similarly, the performances of participation banks operating in Turkey are examined with the help of Entropy and WASPAS methods by Gezen (2019). Çelik (2020), utilized the logistic performance of OECD countries with WASPAS based Entropy method. It was observed that a similar study was applied to the forestry industry by Bayram (2020). Bayram (2020) evaluated the forest industry products of Turkey regarding their economic contribution by Entropy - TOPSIS.

Although it is revealed that Entropy and WASPAS methods are used in the banking and logistics industry in an integrated manner, no previous study has been found in the fisheries and aquaculture industry. Moreover, since there is also a research gap for fisheries and aquaculture industry that focuses on the impact on Turkish foreign trade and economy, this study is expected to contribute to the literature.

In order to meet the purpose, the research framework has been determined as follows.

Step 1: The products were determined according to their average production amounts for the last 5 years and divided into three different groups. The most captured fish, other fish products, and fishes from aquaculture production were evaluated for the Turkish foreign trade.

Step 2: The decision criteria, used for evaluating the products, were determined for the analysis.

Step 3: The selected criteria in the decision matrix were weighted by Entropy method.

Step 4: The products are evaluated and rated according to their contribution to foreign trade by WASPAS method.

Following the introduction section, the importance and purpose of the research are clarified with industrial information and the statistics of Turkey and World. Then, the methods applied in the study are explained in detail. Afterwards, the empirical application has been implemented within the scope of the study's methodology. In the conclusion part of the study, the results are evaluated and interpreted, and suggestions were made for future studies.

\section{MATERIAL AND METHODS}

In this paper, a hybrid MCDM model, Entropy-WASPAS, was utilized for an objective rating. The weights of criteria were calculated by Entropy and the alternatives were evaluated by WASPAS method. In this section, the methods are explained briefly.

\section{Entropy method}

The concept of entropy was developed by using probability theory to measure uncertainty in knowledge by Shannon and Weaver in 1947 (Shemshadi et al., 2011), and was adapted from thermodynamics to information systems by Shannon in 1948 (Santos et al., 2019). Entropy method, which is used in multi-criteria decision-making (MCDM) problems, is an objective weighting method and provides the weighting of the evaluation criteria in the decision matrix ( $\mathrm{Wu}$ and Lin, 2012). The implementation steps of the method are summarized as follows (Li et al., 2011; Ghorbani et al., 2012): 
Step 1: Formation of decision matrix: $x_{i j}$ values are created for $m$ alternatives and $n$ criteria.

$$
\begin{aligned}
& X=\left[\begin{array}{cccc}
x_{11} & x_{12} & \ldots & x_{1 n} \\
x_{21} & x_{22} & \ldots & x_{2 n} \\
\vdots & \vdots & \ldots & : \\
x_{m 1} & x_{m 2} & \ldots & x_{m n}
\end{array}\right] \\
& i=1,2, \ldots, m ; j=1,2, \ldots, n
\end{aligned}
$$

Step 2: Normalization: This process is carried out with the help of the following formula.

$$
p_{i j}=x_{i j} / \sum_{i=1}^{m} x_{i j}
$$

Step 3: Calculation of entropy values $\left(e_{j}\right)$ :

$$
e_{j}=-k \sum_{i=1}^{m} p_{i j} \cdot \ln \left(p_{i j}\right)
$$

Where $\mathrm{k}$ is a constant number provides the expression $0 \leq \mathrm{ej}$ $\leq 1$ and is calculated as $k=1 / \ln (m)$.

Step 4: Determination of degree of difference: The higher the $d_{j}$ values, the higher the significance of the relevant criterion.

$$
d_{j}=1-e_{j}
$$

Step 5: Calculation of weights:

$$
w_{j}=d_{j} / \sum_{j=1}^{n} d_{j}
$$

\section{Weighted aggregated sum product assessment} (WASPAS)

WASPAS was developed by Zavadskas et al (2010), as a combined version of Weighted Sum Model (WSM) and Weighted Product Model (WPM). Steps of the methodology are explained briefly (Chakraborty et al., 2015):

Step 1. Developing the decision matrix.

Step 2. Normalizing the decision matrix.

$$
\bar{x}_{i j}=\frac{x_{i j}}{\max x_{i j}} \quad \text { for beneficial criteria }
$$

$\bar{x}_{i j}=\frac{\min x_{i j}}{x_{i j}}$

for cost criteria

Step 3. The total relative importance of the alternatives is calculated by WSM.

$$
\mathbf{Q}_{\mathbf{i}}^{(\mathbf{1})}=\sum_{\mathbf{j}=1}^{\mathrm{n}} \mathbf{w}_{\mathbf{j}} \mathbf{r}_{\mathrm{ij}}
$$

Step 4. The total relative importance of the alternatives is calculated by WPM.

$$
\mathbf{Q}_{\mathbf{i}}^{(2)}=\prod_{j=1}^{n} \mathbf{r}_{i j}{ }^{w_{j}}
$$

Step 5. The following formula is used to determine the relative and total significance levels of alternatives (Sengupta et al., 2017).

$$
\begin{aligned}
Q_{i}=\lambda Q_{i}^{(1)}+(1 & -\lambda) Q_{i}{ }^{(2)} \\
& =\lambda \sum_{j=1}^{n} \bar{x}_{i j} w_{j}+(1 \\
& -\lambda) \prod_{j=1}^{n}\left(\bar{x}_{i j}\right)^{w_{j}}, \lambda \\
& =0,0.1, \ldots, 1
\end{aligned}
$$

\section{RESULTS}

The products, which were included in the study, were determined according to their average production amounts for the last 5 years which are divided into three different groups as the most captured fishes, other sea products, and fishes from aquaculture production. The production amounts of products were taken from TUIK given in Table 1. The global data as export value, export quantity, import value, and import quantity data were taken from the international trade database TradeMap. Each product's data was selected according to 8 digits of Harmonized Systems (HS) Codes. Therefore, fresh, frozen, dried product types classified under "chapter 03 - Fish and crustaceans, molluscs and other aquatic invertebrates" and prepared-preserved product types classified under the chapter 16 - Preparations of meat, of fish or crustaceans, molluscs or other aquatic invertebrates" were added to the product selection. Ultimately, a detail product selection was made and all products, which were subjected to foreign trade activities of Turkey, were included in all calculations 
Table 1. The most captured and produced species in turkey (tonnes)

\begin{tabular}{lrrrrr}
\hline Type of fish & $\mathbf{2 0 1 5}$ & $\mathbf{2 0 1 6}$ & $\mathbf{2 0 1 7}$ & $\mathbf{2 0 1 8}$ & $\mathbf{2 0 1 9}$ \\
& & & & Quantity of aquaculture production (the most produced) \\
Trout (all types) & 108038.45 & 107013.02 & 109657.33 & 114497.09 & 125745.87 \\
Sea bream & 51844.33 & 58254.08 & 61090.04 & 76680.56 & 99730.67 \\
Sea bass & 75164.44 & 80847.23 & 99971.79 & 116915.07 & 137419.11 \\
& & & Quantity of caught sea fish (the most captured) \\
Sprat & 76995.60 & 50224.90 & 33949.50 & 20056.60 & 38077.60 \\
Atlantic bonito & 4573.00 & 39459.60 & 7577.60 & 30920.40 & 1578.30 \\
Anchovy & 193492.30 & 102595.20 & 158093.80 & 96451.70 & 262544.40 \\
Horse mackerel & 14290.40 & 8859.80 & 8065.60 & 14221.80 & 13179.80 \\
Pilchard & 16693.40 & 18162.10 & 23425.70 & 18854.00 & 19119.20 \\
& & Quantity of caught other sea products (crustaceas, molluscs) (the moct captured) \\
Sea snail & 8795.30 & 10353.70 & 9194.10 & 9672.30 & 11646.30 \\
Prawn (all types) & 3995.20 & 4500.90 & 4730.30 & 4536.10 & 5136.60 \\
Cuttle fish & 744.70 & 925.10 & 986.00 & 1041.90 & 940.10 \\
Mussel (all types) & 37649.40 & 21014.00 & 35476.70 & 45137.40 & 37796.90 \\
\hline S & & & & & \\
\hline
\end{tabular}

Source : TUIK, 2020

The decision matrix was created before starting the analysis. The alternatives were chosen as trout, sea bream, sea bass, sprat, atlantic bonito, anchovy, horse mackerel, pilchard, sea snail, prawn, cuttle fish and mussel. The alternatives were decided according to the statistics of the Republic of Turkey Ministry of Agriculture and Forestry (TAGEM, 2019). The criteria were settled as production quantity, import quantity, import value, export quantity, and export value.

\section{Evaluating the weights of criteria by Entropy method}

The decision matrix is constituted with the last 5 years data of each alternative and criterion. The weighted mean was used for the value-related data while arithmetic mean was used for quantity related data. Table 2 shows the decision matrix.

The weights of the data are calculated and shown in Table 3.

Table 2. Decision matrix

\begin{tabular}{|c|c|c|c|c|c|}
\hline & $\begin{array}{r}\text { Production } \\
\text { (tonnes) }\end{array}$ & $\begin{array}{r}\text { Import quantity } \\
\text { (tonnes) }\end{array}$ & Import value $(\$ 1000)$ & $\begin{array}{r}\text { Export quantity } \\
\text { (tonnes) }\end{array}$ & Export value $(\$ 1000)$ \\
\hline Trout & 112990.00 & 735.00 & 7083.11 & 23477.40 & 117494.84 \\
\hline Sea bream & 69519.60 & 1251.60 & 2967.88 & 68232.20 & 392972.63 \\
\hline Sea bass & 102063.20 & 667.80 & 2120.82 & 17615.00 & 185824.45 \\
\hline Sprat & 43860.84 & 11913.20 & 188.62 & 109.00 & 188.62 \\
\hline Atlantic bonito & 16821.78 & 548.40 & 1233.10 & 12680.80 & 53183.73 \\
\hline Anchovy & 162635.48 & 4695.00 & 3117.40 & 13084.00 & 54751.30 \\
\hline Horse mackerel & 16195.98 & 265.20 & 178.99 & 156.60 & 489.22 \\
\hline Pilchard & 19250.88 & 11974.20 & 8967.69 & 5764.60 & 27066.66 \\
\hline Sea snail & 9932.34 & 223.20 & 847.24 & 1375.80 & 10681.42 \\
\hline Prawn & 4579.82 & 1522.20 & 6046.45 & 674.00 & 5949.44 \\
\hline Cuttle fish & 927.56 & 1192.20 & 9156.10 & 336.20 & 1953.99 \\
\hline Mussel & 35414.88 & 477.20 & 1718.72 & 16.80 & 232.42 \\
\hline
\end{tabular}

Table 3. The weights of the criteria

\begin{tabular}{cccccc}
\hline & $\begin{array}{c}\text { Production } \\
\text { (tonnes) }\end{array}$ & $\begin{array}{c}\text { Import quantity } \\
\text { (tonnes) }\end{array}$ & Import value $(\mathbf{\$ 1 0 0 0 )}$ & $\begin{array}{c}\text { Export quantity } \\
\text { (tonnes) }\end{array}$ & $\begin{array}{c}\text { Export value } \\
(\$ 1000)\end{array}$ \\
\hline$w_{j}$ & 0.135 & 0.220 & 0.112 & 0.262 & 0.271 \\
\hline
\end{tabular}




\section{Evaluating the alternatives by WASPAS method}

After calculating the weights, WASPAS method was used for evaluating the alternatives. According to the Equations (67 ), normalized decision matrix is found as in Table 4. After normalizing the decision matrix, applying Equations (8-10), the relative and total significance levels of alternatives are calculated as in Table 5.

\section{Scenario analysis}

In the last part of the application, to search the differences in the rankings and the robustness of proposed methodology, a scenario analysis consists of 5 scenarios is conducted and the results are compared. The result of scenario analysis is shown in Table 6. Also, Figure 3 shows the graphical display.

Table 4. Normalized decision matrix

\begin{tabular}{|c|c|c|c|c|c|}
\hline & $\begin{array}{c}\text { Production } \\
\text { (tonnes) }\end{array}$ & $\begin{array}{c}\text { Import quantity } \\
\text { (tonnes) }\end{array}$ & Import value $(\$ 1000)$ & $\begin{array}{c}\text { Export quantity } \\
\text { (tonnes) }\end{array}$ & $\begin{array}{c}\text { Export value } \\
(\$ 1000)\end{array}$ \\
\hline Trout & 0.695 & 0.304 & 0.025 & 0.344 & 0.299 \\
\hline Sea bream & 0.427 & 0.178 & 0.060 & 1.000 & 1.000 \\
\hline Sea bass & 0.628 & 0.334 & 0.084 & 0.258 & 0.473 \\
\hline Sprat & 0.270 & 0.019 & 0.949 & 0.002 & 0.000 \\
\hline Atlantic bonito & 0.103 & 0.407 & 0.145 & 0.186 & 0.135 \\
\hline Anchovy & 1.000 & 0.048 & 0.057 & 0.192 & 0.139 \\
\hline Horse mackerel & 0.100 & 0.842 & 1.000 & 0.002 & 0.001 \\
\hline Pilchard & 0.118 & 0.019 & 0.020 & 0.084 & 0.069 \\
\hline Sea snail & 0.061 & 1.000 & 0.211 & 0.020 & 0.027 \\
\hline Prawn & 0.028 & 0.147 & 0.030 & 0.010 & 0.015 \\
\hline Cuttle fish & 0.006 & 0.187 & 0.020 & 0.005 & 0.005 \\
\hline Mussel & 0.218 & 0.468 & 0.104 & 0.000 & 0.001 \\
\hline
\end{tabular}

Table 5. The relative and total significance levels of alternatives

\begin{tabular}{lcccc}
\hline & $Q_{i}^{(1)}$ & $Q_{i(2)}$ & $Q_{i}(\lambda=0.5)$ & Rating \\
\hline Trout & 0.335 & 0.264 & 0.299 & 3 \\
Sea bream & 0.637 & 0.445 & 0.541 & 1 \\
Sea bass & 0.364 & 0.320 & 0.342 & 2 \\
Sprat & 0.148 & 0.008 & 0.078 & 8 \\
Atlantic bonito & 0.205 & 0.182 & 0.194 & 4 \\
Anchovy & 0.240 & 0.141 & 0.191 & 5 \\
Horse mackerel & 0.312 & 0.023 & 0.168 & 7 \\
Pilchard & 0.063 & 0.051 & 0.057 & 10 \\
Sea snail & 0.264 & 0.078 & 0.171 & 6 \\
Prawn & 0.046 & 0.026 & 0.036 & 11 \\
Cuttle fish & 0.047 & 0.013 & 0.030 & 12 \\
Mussel & 0.144 & 0.008 & 0.076 & 9 \\
\hline
\end{tabular}


Table 6. Results of scenario analysis

\begin{tabular}{|c|c|c|c|c|c|c|c|c|c|c|}
\hline Scenarios & & 1 & & 2 & & 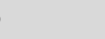 & & & & ; \\
\hline \multirow{6}{*}{ Weights } & $w_{1}$ & 0.135 & $\mathbf{w}_{1}$ & 0.271 & $\mathbf{w}_{1}$ & 0.135 & $W_{1}$ & 0.135 & $w_{1}$ & 0.135 \\
\hline & $\mathbf{w}_{2}$ & 0.220 & $w_{2}$ & 0.220 & $w_{2}$ & 0.271 & $w_{2}$ & 0.220 & $w_{2}$ & 0.220 \\
\hline & $\mathbf{W}_{3}$ & 0.112 & $w_{3}$ & 0.112 & $W_{3}$ & 0.112 & $w_{3}$ & 0.271 & $\mathbf{w}_{3}$ & 0.112 \\
\hline & $\mathrm{W}_{4}$ & 0.262 & $w_{4}$ & 0.262 & $\mathrm{w}_{4}$ & 0.262 & $w_{4}$ & 0.262 & $W_{4}$ & 0.271 \\
\hline & $W_{5}$ & 0.271 & $W_{5}$ & 0.135 & $W_{5}$ & 0.220 & $W_{5}$ & 0.112 & $W_{5}$ & 0.262 \\
\hline & $c_{j}$ & ranking & $c_{j}$ & ranking & $c_{j}$ & ranking & $c_{j}$ & ranking & $c_{j}$ & ranking \\
\hline Trout & 0.299 & 3 & 0.342 & 3 & 0.300 & 3 & 0.235 & 4 & 0.300 & 3 \\
\hline Sea bream & 0.541 & 1 & 0.478 & 1 & 0.501 & 1 & 0.386 & 1 & 0.541 & 1 \\
\hline Sea bass & 0.342 & 2 & 0.359 & 2 & 0.335 & 2 & 0.273 & 2 & 0.340 & 2 \\
\hline Sprat & 0.078 & 8 & 0.102 & 8 & 0.079 & 9 & 0.163 & 8 & 0.078 & 8 \\
\hline Atlantic bonito & 0.194 & 4 & 0.188 & 5 & 0.206 & 4 & 0.195 & 6 & 0.194 & 4 \\
\hline Anchovy & 0.191 & 5 & 0.271 & 4 & 0.185 & 7 & 0.175 & 7 & 0.191 & 5 \\
\hline Saurel & 0.168 & 7 & 0.184 & 6 & 0.194 & 6 & 0.269 & 3 & 0.168 & 7 \\
\hline Pilchard & 0.057 & 10 & 0.062 & 10 & 0.054 & 10 & 0.049 & 10 & 0.057 & 10 \\
\hline Sea snail & 0.171 & 6 & 0.178 & 7 & 0.204 & 5 & 0.201 & 5 & 0.171 & 6 \\
\hline Shrimp & 0.036 & 11 & 0.038 & 11 & 0.041 & 11 & 0.039 & 11 & 0.036 & 11 \\
\hline Cuttle fish & 0.030 & 12 & 0.030 & 12 & 0.036 & 12 & 0.033 & 12 & 0.030 & 12 \\
\hline Mussel & 0.076 & 9 & 0.096 & 9 & 0.090 & 8 & 0.089 & 9 & 0.076 & 9 \\
\hline
\end{tabular}

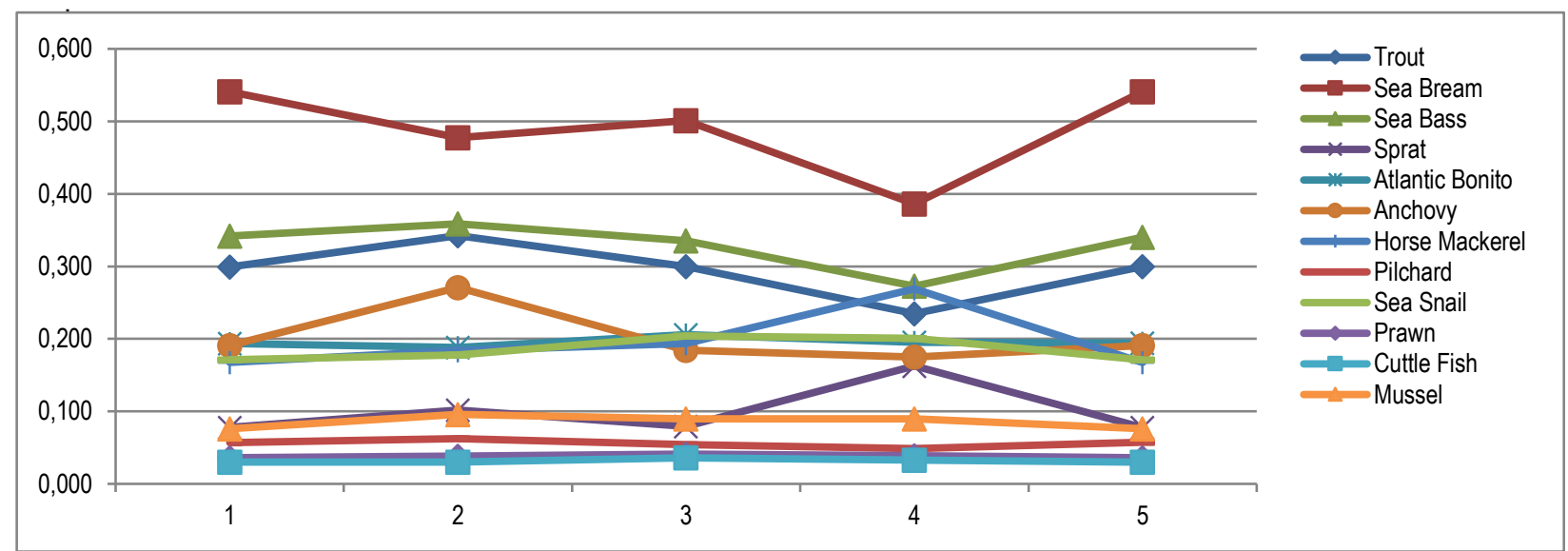

Figure 3. Scenario analysis

As can be seen from the scenarios, when we change the weights of the criteria, the order of fishery products does not change. For all the scenarios, Sea Bream is found as the most valuable fishery product. And also, cuttle fish is found as the least valuable fishery product for Turkey.

\section{CONCLUSION}

The fisheries and aquaculture industry is one of the leading industries in Turkey which has a significant importance in contributing to nutrition and food security, as well as offering a wide range of employment opportunities and having a high trade potential. Scientific researches of the last 50 years have much improved the understanding of fisheries and aquaculture industry, and global awareness for the need of managing the industry in a sustainable approach. However, less attention has been given to its important role in foreign trade which plays as one of the key drivers of economic activities, in generating regional employment and as a source 
of foreign exchange. In this context, this paper focused on showing this importance by the help of determining the products providing the greatest contribution to the foreign trade of Turkey. Furthermore, Entropy-WASPAS, which is a hybrid multi-criteria decision-making method was applied to evaluate the products.

Following the steps of Entropy method, the results in Table 3 shows that the most important criterion is the export value $(0.271)$, whereas the least important is import value (0.112). Then WASPAS method was used for ranking the alternatives. The results show that sea bream is the most valuable and cuttle fish is found as the least valuable fishery product for Turkey. Since fishery products are evaluated in terms of trade data, products with high import data like cuttle fish, prawn and pilchard are found to contribute less to the economy. Besides, since its export value and quantity is high,

\section{REFERENCES}

Akçakanak, Ö., Eren, H., Aksoy, E. \& Ömürbek, V. (2017). Bankacılık sektöründe entropi ve WASPAS yöntemleri ile performans değerlendirmesi. Süleyman Demirel Üniversitesi İktisadi ve İdari Bilimler Fakültesi Dergisi, 22 (2), 285-300.

Ali, J., Bashir, Z. \& Rashid, T. (2021). WASPAS-based decision-making methodology with unknown weight information under uncertain evaluations. Expert Systems with Applications, 168, 1-18. DOI:10.1016/j.eswa.2020.114143

Bayram, B.Ç. (2020). Evaluation of forest products trade economic contribution by Entropy-TOPSIS: Case study of Turkey. BioResources, 15(1), 1419-1429. DOI:10.15376/biores.15.1.1419-1429

Chakraborty, S., Zavadskas, E.K. \& Antucheviciene, J. (2015). Applications of WASPAS method as a multi-criteria decision-making tool. Economic Computation and Economic Cybernetics Studies and Research, 49(1), 5-22, 2015.

Çelik, P. (2020). Entropi tabanlı WASPAS yöntemi ile lojistik performansın değerlendirilmesi: OECD ülkeleri örneği. Lojistik Dergisi, 51, 28-38.

FAO, (2020). The state of world fisheries and aquaculture - sustainability in action. Rome. 224 pp. Retrieved on December 4, 2020 from http://www.fao.org/3/ca9229en/ca9229en.pdf

Gezen, A. (2019), Türkiye'de faaliyet gösteren katılım bankalarının entropi ve WASPAS yöntemleri ile performans analizi. Muhasebe ve Finansman Dergisi, 84, 213-232. DOI:10.25095/mufad.625812

Ghorbani, M., Bahrami, M. \& Arabzad, S.M. (2012). An integrated model for supplier selection and order allocation; using Shannon Entropy, SWOT and Linear Programming. Procedia. Social and Behavioral Sciences, 41, 521 - 527. DOI:10.1016/j.sbspro.2012.04.064

Hixson, S.M. (2014). Fish nutrition and current issues in aquaculture: the balance in providing safe and nutritious seafood, in an environmentally sustainable manner. Journal of Aquaculture Research and Development, 5(3), 1-10. DOI:10.4172/2155-9546.1000234

Li, X., Wang, K., Liu, L., Xin, J., Yang \& H., Gao, C. (2011). Application of the Entropy weight and TOPSIS method in safety evaluation of coal mines. although its production is less, sea bream is considered to be more valuable for the country's economy than its closest competitors, Trout and Sea Bass.

Evaluating the stability of the results, scenario analysis was conducted. According to 5 scenarios, supporting the paper, sea bream is found as the most valuable and cuttle Fish is found as the least valuable fishery product for Turkey. Thusly, the robustness of the methodology is shown.

There are some limitations about the field of the study and methods. In this study we investigated the most produced and found fishery products in Turkey. For further research, all fishery products in Turkey can be investigated. On the other hand, Entropy and WASPAS methods are applied in this study. Besides, using different Multi-Criteria Decision Making models such as SWARA, ELECTRE, VIKOR etc. in future research can contribute to the literature.

Procedia Engineering, 26, 2085-2091.

DOI:10.1016/j.proeng.2011.11.2410

OECD Library (2020), OECD Agriculture Statistics, Retrieved on December 8,2020 from https://www.oecd-ilibrary.org/agriculture-andfood/data/oecd-agriculture-statistics_agr-data-en

Santos, B.M., Godoy, L.P. \& Campos, L. M.S. (2019). Performance evaluation of green suppliers using Entropy-TOPSIS-F. Journal of Cleaner Production, 207, 498-509. DOI:10.1016/j.jclepro.2018.09.235

Sengupta, R.N., Gupta, A. \& Dutta, J. (2017). Decision Science: Theory and Practice. UK: CRC Press Taylor \& Francis Group. DOI: $10.1201 / 9781315183176$

Shemsadi, A., Shirazi, H., Toreihi, M. \& Tarokh, M.J. (2011). A fuzzy VIKOR method for supplier selection based on Entropy measure for objective weighting. Expert Systems with Applications, 38, 12160-12167. DOI:10.1016/j.eswa.2011.03.027

STASTISTA (2020), Fisheries and Aquaculture Statistics. Retrieved on December 8, 2020 from https://www.statista.com

TAGEM (2019), General Directorate of Agricultural Research and Policy. https://www.tarimorman.gov.tr/TAGEM/Belgeler/yayin/Su\%20Ürünleri\%2 OSektör\%20Politika\%20Belgesi\%202019-2023.pdf

TUIK, (2020), Fisheries and Aquaculture Statistics. Retrieved on December 2, 2020 from http://www.tuik.gov.tr

Ural, M., Demireli, E. \& Özçalık, S.G. (2018). Kamu bankalarında performans analizi: Entropi ve WASPAS yöntemleri ile bir uygulama. Pamukkale Üniversitesi Sosyal Bilimler Enstitüsü Dergisi. 31, 129-141. DOI:10.30794/pausbed.414721

Wu, H.-Y. \& Lin, H.-Y. (2012). A hybrid approach to an analytical model for enhancing the service quality of e-learning. Computers\&Education. 58, 1318-1338. DOI:10.1016/j.compedu.2011.12.025

Zavadskas, E.K., Turskis, Z. \& Vilutiene, T. (2010). Multiple criteria analysis of foundation instalment alternatives by applying additive ratio assessment (ARAS) method. Achieves of Civil and Mechanical Engineering. 10 (3), 123-141. DOI:10.1016/S1644-9665(12)60141-1 